University of Texas Rio Grande Valley

ScholarWorks @ UTRGV

Winter 2018

\title{
"A Bunch of Tough Hombres": Police Brutality, Municipal Politics, and Racism in South Texas
}

Brent M. S. Campney

The University of Texas Rio Grande Valley, brent.campney@utrgv.edu

Follow this and additional works at: https://scholarworks.utrgv.edu/hist_fac

Part of the History Commons

\section{Recommended Citation}

Campney, Brent M. S. "'A Bunch of Tough Hombres": Police Brutality, Municipal Politics, and Racism in South Texas." Journal of the Southwest, vol. 60, 2018, p. 787-825. Project MUSE, doi:10.1353/ jsw.2018.0016.

This Article is brought to you for free and open access by the College of Liberal Arts at ScholarWorks @ UTRGV. It has been accepted for inclusion in History Faculty Publications and Presentations by an authorized administrator of ScholarWorks@ UTRGV. For more information, please contact justin.white@utrgv.edu, william.flores01@utrgv.edu. 


\section{YEARS}

\section{PROJECT MUSE}

\section{"A Bunch of Tough Hombres": Police Brutality, Municipal}

Politics, and Racism in South Texas

Brent M. S. Campney

Journal of the Southwest, Volume 60, Number 4, Winter 2018, pp. 787-825 (Article)

Published by The Southwest Center, University of Arizona

DOI: https://doi.org/10.1353/jsw.2018.0016

$\Rightarrow$ For additional information about this article https://muse.jhu.edu/article/721659 


\title{
"A Bunch of Tough Hombres": Police Brutality, Municipal Politics, and Racism in South Texas
}

\author{
Brent M. S. Campney
}

"Everybody knew the McAllen police were a bunch of tough hombres, especially the Boys on C shift," reported the Dallas Morning News on March 29, 1981. "Working the midnight-to-8 a.m. shift along the border is like being at war, the cops said. You have to be tough. The Boys on C shift worked at being tough." Many of the "Boys" wore black T-shirts with gold letters bearing “the legend, 'C Shift Animals.' They even had their own slogan: 'Kick... and Ask Questions Later.' ” Only days earlier, the public had become aware of their misdeeds, revealed in six years of booking room videos recorded by the McAllen Police Department (MPD) and subpoenaed by a civil rights attorney. On these videos Anglo and Mexican American officers alike confirmed suspicions that they had beaten, kicked, and abused prisoners - in virtually all cases, working-class Mexican Americans. ${ }^{1}$

Station KGBT in nearby Harlingen played television footage of the beatings, bringing a flood of outrage. "One woman, like many of the callers, was almost in tears when she thanked us over and over again for showing such terrible things going on," noted a representative of the station. "She said as soon as she got through talking to us, she was going to call the McAllen police to demand an answer [as to] why those things had happened."2 She was not alone. "The police switchboard was lit up for hours after the tapes were shown on TV," declared James C. Harrington, the attorney for the American Civil Liberties Union (ACLU), which had secured the videos and released them to the media. ${ }^{3}$ As investigators probed the scandal, some pointed to the mayor-already locked in a heated, racially tinged political race with Ramiro Casso, a Mexican American challenger-as an enabler. On May 3 the News reported that "the federal grand jury investigation of accusations of

Brent M. S. Campney is associate professor in the Department of History at the University of Texas Rio Grande Valley. 
brutality by McAllen police has broadened to include the possibility of a cover-up of the incidents by Mayor Othal Brand and other city officials." 4

This study tells the story of the 1981 MPD scandal, its impact on the ongoing municipal election between an Anglo incumbent and a Mexican American challenger, and its role in unifying Mexican Americans in South Texas during a period in which they were beginning to seize the reigns of local and regional power. Historians such as David Montejano, Marc Simon Rodriguez, and Brian Behnken have incorporated the issue of police brutality into their scholarship on the Mexican American civil rights movement during the post World War II period. In his discussion of Colorado, for example, Rodriguez found that between "1962 and 1964, police brutality became a significant issue for Mexican Americans in Denver and was the spark that ignited community activism. Several young men had had interactions with the police, and what should have been no more than minor skirmishes led to the young men's deaths."5 Nevertheless, historians have focused on particularly egregious incidents in places like East Los Angeles and Dallas rather than on the issue of police violence more broadly. This study places police violence at the center of the story and addresses its significance in enforcing repression, promoting resistance, and transforming local and regional power relations. ${ }^{6}$

The study proceeds in five sections. In the first it details the history of police violence against Mexican Americans in Texas and in the Lower Rio Grande Valley (hereafter, the Valley) in the 1970s. In the second section it examines the role in these events of Othal Brand, the so-called Onion King, who owned one of the most powerful agribusiness interests in Texas and served as the mayor of McAllen. In the third it analyzes the MPD scandal, the roots of which dated back to the early 1970s. In the fourth it explores the mayoral campaign, election, and election runoff, all of which not only highlighted the police scandal but underlined racial and class divisions in this South Texas city. In the final section it considers the historiographical implications of its findings.

To tell this story, I draw upon an array of sources. Among these I include news reports, interviews, and editorials in local and regional Anglo newspapers, particularly the McAllen Monitor and the Dallas Morning News; articles and advertisements published in the popular magazine Texas Monthly; and material printed in the farmworkers newsletter, El Cubamil, published in nearby San Juan. I also employ the collected papers of Ramiro Casso, a Mexican American doctor and civil rights leader, and a long-term political and ideological opponent of Brand. 
In 1980 McAllen was a Valley city of some 66,000 residents located in the heart of the South Texas citrus belt. "This sunbaked city hugs the Mexican border along the Rio Grande River at the bottom of what is known here simply as the Valley, a vast expanse of Texas that sweeps down from San Antonio through hostile ranch land until palm trees dominate the skyline and citrus trees nurture the economy," wrote the Washington Post in 1981. "At dark, along the highway that runs north out of McAllen, the lights burn brightly at the processing plants, and the fragrance of onions and cantaloupe sweetens the warm tropical air. The odor is powerful in its freshness, seductive as it hangs in the humid night."7 Between 1970 and 1980, McAllen had increased in size from just 37,636 residents to 66,281, 70 percent of them Mexican American. ${ }^{8}$

McAllen was the business capital of the Valley and, after Brownsville, its largest city. It was founded in 1904 after the construction of a new railroad connecting the region to the national market. Over the following decade Anglo farmers invaded the area and, using the twin levers of fraud and violence, gained control of the ranch lands largely controlled heretofore by Mexican American cattle ranchers. After dispossessing the Mexican Americans, they put many of them to work as stoop-laborers in the new agricultural empire that they created. Following a series of 1915 raids by a small network of ethnic Mexican revolutionaries eager to drive out the Anglos and reclaim their lands, the Anglos consolidated their control with a massacre in which hastily deputized Texas Rangers and lynch mobs killed hundreds of persons of Mexican descent, if not more. In the years thereafter, they imposed increasingly harsh Jim Crow measures to chain Mexican Americans to the bottom of the social order. 9

Throughout the balance of the twentieth century, Mexican Americans challenged the Anglo order. Following the aforementioned massacre in 1915, Brownsville State Representative J. T. Canales, an influential Mexican American, pressed vigorously for an investigation into the conduct of the Texas Rangers, an inquiry which led to the eventual restructuring of that police organization. In 1929 elite Mexican American men formed the League of United Latin American Citizens (LULAC) in Corpus Christi and, despite its initial (and enduring) classist and sexist orientation, they fought with vigor to overthrow racist practices across the state and to open new opportunities for their people. From the 1930s to the 1950s, LULAC used political and economic pressure, as well as court challenges, to compel Anglo leaders to abandon their proscriptions against Mexican Americans in virtually all realms of life, efforts that bore 
some (often short-term) benefits. To their frustration, however, Mexican Americans routinely discovered that Anglos had once again resurrected the Jim Crow indignities previously negotiated away. 10

After World War II, and particularly during the late 1960s and early 1970s, Mexican Americans challenged Jim Crow with a broader-based and more confrontational approach. "Organizers during the 1960s began challenging segregated school systems and city councils, making neverbefore-seen inroads for South Texas Mexicans," wrote historian Timothy Paul Bowman."1 On June 1, 1966, hundreds of Mexican American farmworkers organized one of the largest strikes ever undertaken in the region. After striking for a month, they then undertook a "nearly fivehundred-mile Minimum Wage March" to Austin "to garner media attention for the plight of the laborers." 12 With such efforts, they made some gains. Nonetheless, many Anglos still insisted well into the 1970s that their "Mexicans" were generally satisfied with their circumstances. At the same time, however, they revealed increasing bitterness that some "Mexicans" had begun expressing openly their intolerance of the status quo.

Anglos claimed to be surprised, therefore, when the freedom struggle revealed smoldering anger. In 1970 a woman in Mathis felt betrayed by what she perceived as an inexplicable turn against Anglos by ungrateful Mexican Americans, whom she called "Mexicans." Mathis was "a wonderful little town with lots of good people in it, Mexicans and Anglos," she said. "It was a wonderful town, that is," until Mexican Americans and a few Anglos organized their own candidate for mayor. She charged that the civil rights movement "really has no purpose. The majority of Mexicans don't want it. Just some of the young. The problem isn't the older Mexican. It's the young ones," whom she decried as communists. She feared that a few troublemakers had spoiled the good ones. "The Mexican was really making progress," she mourned. "I've seen them progress so far in their methods of eating, sleeping, drinkingthose things. They have come a long way. I don't look down on them because some of my best friends are Mexicans."13

Rather than admit that they had long enforced Jim Crow and consider, perhaps, ways that they might atone for that injustice, many Anglos remembered-falsely, of course - that both Anglos and Mexican Americans alike had been happy with the status quo until the mid-1960s when the latter made unjustifiable demands and stirred up ugliness. An Anglo made this point in 1981 as she fondly recalled the 1960s when, 
"if we can all reflect back that far, the people of McAllen and the entire Valley lived together in harmony side by side REGARDLESS of whether we were 'gringos' or 'Mexicans' "- a memory plainly inconsistent with that held by many Mexican Americans. 14

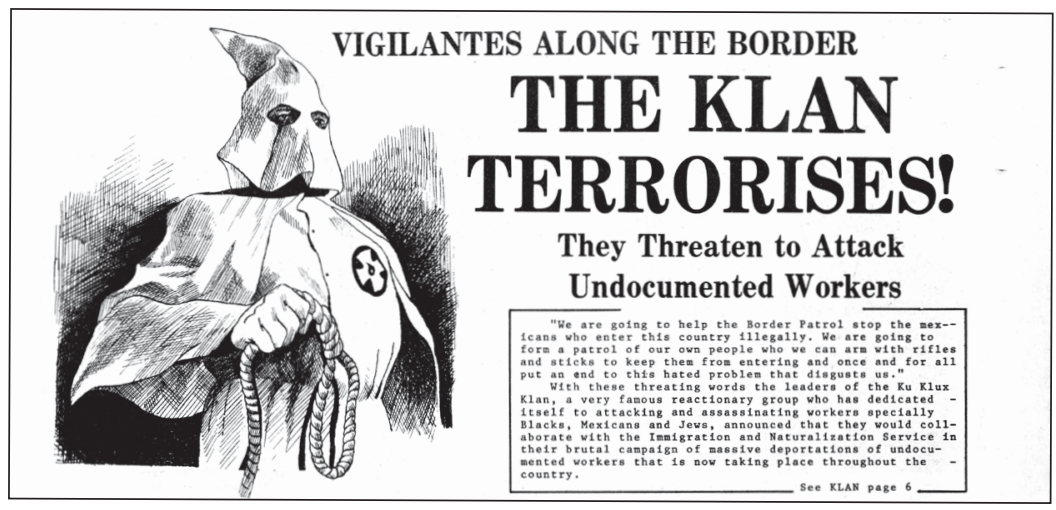

This sensational image indicates the level of inter-racial friction in the Valley during the study period and the sort of racist animosity directed at persons of Mexican descent. Image in "Vigilantes along the Border," reproduced in El Cuhamil, November 5, 1977, p. 1. Courtesy of Library Special Collections \& University Archives, University of Texas Rio Grande Valley.

\section{Police Violence in Texas and the Rio Grande Valley}

In the 1970s, violence against working-class Mexican Americans by local police officers was a major-if unsurprising - issue in Texas during a period of vigorous Chicano activism. It was very common indeed in the Rio Grande Valley. On December 10, 1970, Deputy Sheriff Nem Jennings Bryan killed fourteen-year-old Victor Manuel Nava in Brownsville. He claimed that he spotted some youths sniffing glue in an alley and gave chase until compelled to defend himself. "Bryan said after the shooting he fired only after Nava lunged at him with what Bryan thought was a knife," reported the News. "However, no knife was found." 15 Despite the supposed lunge, Bryan "shot Nava in the back of the head." 16 Nevertheless, the state grand jury declined to prosecute and the authorities in Cameron County refused to investigate.

Once it became clear that the Texas authorities would do nothing, 
the Justice Department assumed responsibility. "U.S. Attorney Anthony J. P. Farris has ordered the FBI to investigate," a reporter noted. "As is our policy, we waited until the matter was handled locally,' Farris said. 'It is apparent there was no vigorous prosecution of the case.' "17 A federal grand jury soon indicted Bryan for violating Nava's civil rights by depriving him of his life without due process. At the April trial, however, Bryan won an easy acquittal. Evidently, the jury agreed with the defense attorney who "accused the Justice Department in final arguments of putting 'lying little glue sniffers' on the stand to testify against Bryan." In making their decision, the jurors deliberated for just forty-four minutes. 18

Less than three months after the Nava killing, Mexican American youths "picketed the Pharr police station to protest the beating of two Chicanos in the jailhouse," explained the Grito del Norte. ${ }^{19}$ Alerted to the protest, police from neighboring Edinburg and McAllen, and state troopers from Harlingen, hurried to assist their fellows. Unsuccessful in dispersing the crowd, they appealed to the Pharr fire department to deploy water hoses. When some of the youths responded with projectiles, the officers reacted with a full-scale charge, sweeping through the main streets, firing guns into the air. Before the night was over, they had turned the "street in front of the police station [into a] scene of broken glass, hurled rocks, tear gas and discharging riot guns." 20

During the chaos an officer shot and killed Alfonso Flores, an innocent victim who had simply exited a shop. In addition, the police arrested dozens of youths.21 "Another Chicano brother has been murdered by police," thundered the Grito del Norte. "Flores was shot in the head as he stood watching over 100 Texas Rangers, Highway Patrolmen and police sweep through the [Pharr] barrios using tear gas, clubs and guns against the terrorized people." 22 After addressing a thousand students at Pan American College in neighboring Edinburg, national Mexican American civil rights activist César Chávez, coincidentally visiting the area, commented on the riot. "'We can't tolerate that kind of action by the Pharr police. They (the demonstrators) wanted to protest widespread police brutality and it escalated into a demonstration." 23

Although the violence attributed to the MPD lacked the drama which attracted attention to the killings of Mexican Americans in Brownsville and Pharr, McAllen was the epicenter of police violence in the Valley. In the 1970 s it provided "many young men along the border" with a "bitter 
lesson" of its widespread reputation for unwarranted violence by its police officers. ${ }^{24}$ As the Dallas Morning News reported, "the troubled police department in McAllen...has been the target of numerous complaints of brutality and misconduct since 1976." 25 Reviewing the history of beatings when the video record surfaced in 1981, State Representative Arnold Gonzales, a Democrat from Corpus Christi, probably spoke for many Mexican Americans when he declared: "I ain't ever going to go to McAllen." 26

Almost by definition, officers served the interests of Anglos and, particularly, the middle- to upper-class Anglos who ran the city. Furthermore, many of the assaulting officers were Anglos. However, when empowered with a badge, Mexican Americans could exhibit the same behavior, knowing that they too could avoid the consequences and, at the same time perhaps, ingratiate themselves with Anglos. Furthermore, as historians recognize, some Mexican Americansparticularly the more prosperous ones-shared Anglo contempt for poor and working-class Mexican Americans. In his remarks after the Pharr riot, César Chávez made this point: "Mexicans can be just as brutal as Anglos."27 After the reports of the violence in McAllen, an observer suggested that it "wasn't necessarily a racial issue." The videos showed "that Mexican cops and Anglo cops were involved in beating prisoners. Of course, the prisoners they were beating were all Hispanics. That's [also] very clear." 28 T. F. Rocha, a resident of McAllen, expressed anger at the racism and classism on vivid display. "Those police officers acted like a bunch of cowards beating up poor Mexican-Americans," he observed. "They were mostly arrested because they were poor and Mexican-Americans, and because these cops probably thought they could get away with [it]."29

\section{The Onion King}

"McAllen Mayor Othal Brand, the self-proclaimed onion king, knew he didn't want to be poor when he grew up," wrote reporter David Sedeno in a 1985 profile. The "multi-millionaire agribusinessman doesn't have to worry too much about money; in fact he is divesting much of his personal estate." 30 As the chairman of Griffin \& Brand, a citrus and vegetable packing company, Brand advised American presidents and 
Texas governors, was a philanthropist, and held honorary doctorates even though he had never completed high school. "Othal Brand could have stepped out of the pages of a Horatio Alger novel," summarized Texas Monthly. 31

Born poor in Georgia in 1919, Brand was peddling produce at ten years of age and went into business for himself at sixteen. Crisscrossing the country as a produce buyer in 1938, he "journeyed for the first time to the Rio Grande Valley, from where one day he would run his empire." He served as a marine in World War II and married in 1945. Following his military service, he returned to his business activities in Atlanta. ${ }^{32}$ However, on numerous occasions thereafter he visited the "tropical Rio Grande Valley, the 'Magic Valley' where crops flourish year-round. He scoured the countryside, buying up dozens of acres here and there. In 1953, after more than ten years of shuttling back and forth between Georgia and the Valley, Brand and his family moved to Texas permanently and built an agricultural empire that now spans the globe. He owns 40,000 acres in Texas, Colorado, Idaho, and California. No matter the time of year, the conveyor belts at Brand's huge McAllen packing plant are laden with onions, cabbage, cantaloupes, bell peppers, or strawberries." 33 By the mid-1980s, he had built a business with a value estimated at $\$ 77$ million. 34

Tall, muscular, and athletic, Brand was a devout Southern Baptist and Sunday school teacher who "hates high-ranking state Democrats, liberals and union activists." Focused, self-righteous, and strong-willed, he directed his attention initially to his business, which prospered along with his adopted and rapidly growing South Texas hometown. Within a decade of his arrival there he turned his attention to active political engagement. ${ }^{35}$ Beginning in 1960, he served on the school board, a tenure marked "by temper tantrums when members didn't go along with him," noted Texas Monthly. "In fact, once Brand became so angry at a board member who voted against a pet project that he struck the man." 36

After eight years on the school board he served four years on the city commission before ousting the "establishment" incumbent mayor in 1977. Although he remained controversial, he would retain his mayoral position for the next twenty years. In his 1985 article Sedeno indicated that Brand, an Anglo, was serving his "third term as mayor in a city where Mexican Americans make up 85 percent of the population but a Hispanic has never been elected mayor." Although many residentsparticularly the Mexican Americans-remained poor, Brand helped to 
transform McAllen into a juggernaut, boasting that he was building the "greatest city in South Texas." Indeed, he was. Between 1980 and 1985 the population there increased by more than 20 percent and, with its subtropical climate, U.S. News \& World Report named it "one of the 10 best U.S. cities in which to retire." As Brand put it: "I'm a doer. I like to build things." He admitted that he had done things that he regretted but he believed that on the whole his life had "been one of contribution to society, to my nation and to God." 37

For all his accomplishments, critics charged, "Brand also has another side." 38 Fellow Anglo politicians and businessmen grumbled that the notoriously independent Brand acted without concern for their views. Campaigning against him in 1981, fellow mayoral candidate Mike Frost - who represented the Anglo establishment overthrown by Brandcaptured a widespread criticism. "McAllen needs cooperation and leadership, and isn't getting much of either from its current mayor," he told supporters. "The trouble with Othal Brand is that he doesn't know what the word "we' means." 39 Making this the theme of his campaign, Frost charged that for "four years, McAllen has been ruled by 'The Law According to Othal Brand.' " This, he asserted, was "the same law that repeatedly cuts citizens short at City Commission meetings" and that this was the time to "elect a mayor who respects the law and the wishes of the people." 40

Mexican Americans, and particularly the working-class majority, charged that Brand had "forgotten the poor, intimidates farmworkers, is a bully, a racist." ACLU attorney Harrington, who had "sued Brand countless times on behalf of farmworkers," viewed the Onion King as a prime exploiter of Mexican American and undocumented Mexican labor. Brand, he claimed, had "a real violent tendency especially to those who disagree with him. He can be very vindictive." He added that "farmworkers in the Valley fear Brand, who insists he's the farmworker's best friend." Brand rejected the racist label but did not dispute Harrington's charge that he liked to get even: "I don't forget injustices.... I just mark it in the back of my mind and catalog it. But I don't forget." 41 In 1981 a labor organizer described Brand as "Mr. Agribusiness," the local "spokesman against collective bargaining rights for workers." 42 Texas Monthly acknowledged that there was "a lot of bad blood - and lawsuitsbetween Brand and the farmworker organizers. He is perhaps their most formidable obstacle." 43 


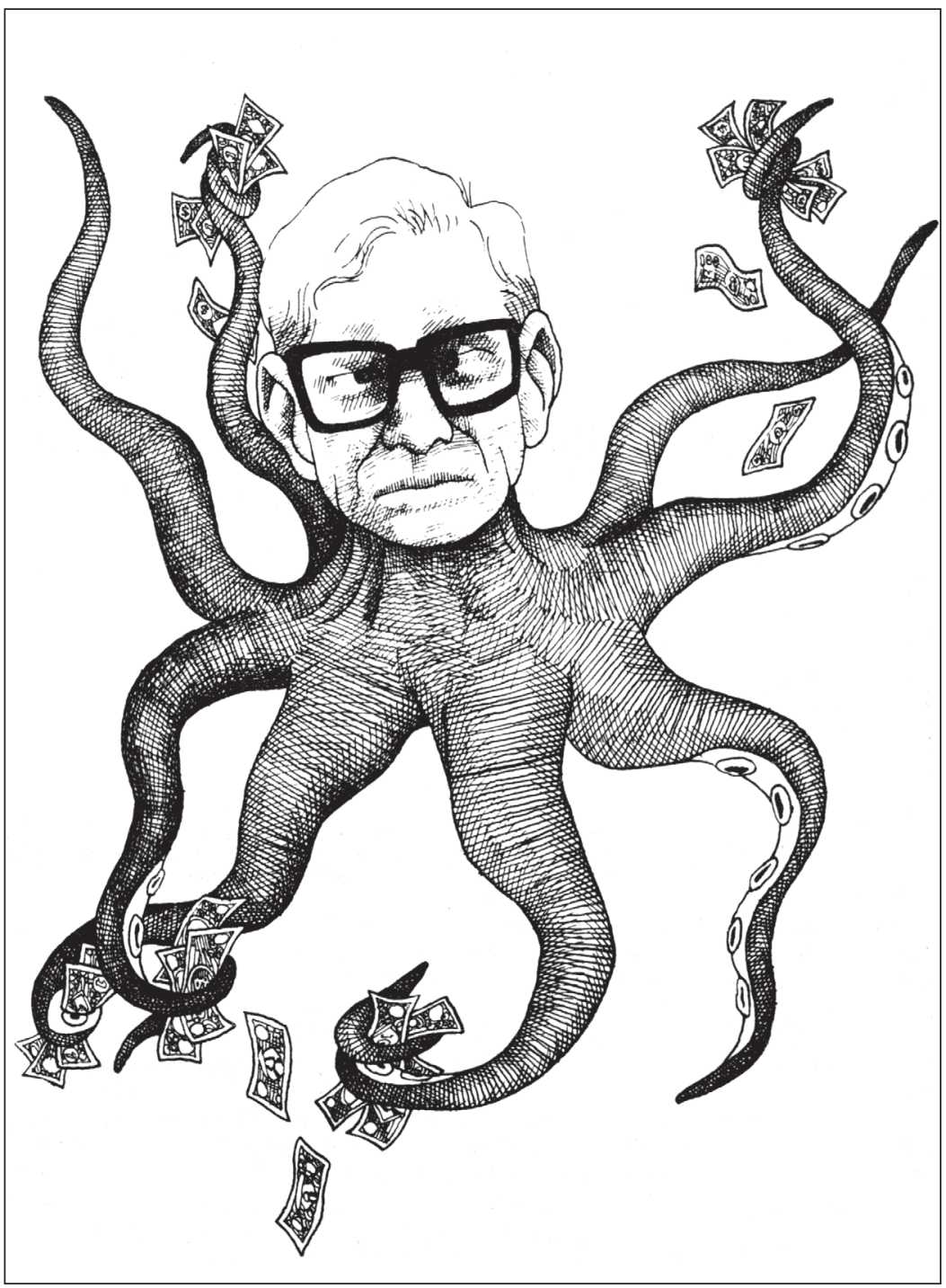

This cartoon image of Othal Brand depicts the wealthy Anglo businessman and politician as an octopus, with his eight money-clutching tentacles involved in nearly every aspect of the local social order. From El Cuhamil, last issue of 1979, p. 3. Courtesy of Library Special Collections \& University Archives, University of Texas Rio Grande Valley. 
Brand revealed his tough side in a 1975 skirmish with farmworkers who were working "feverishly to organize a union." During a wildcat strike by melon workers, in which organizers of the United Farm Workers played a significant role, "a television crew filmed Brand as he jumped out of his pickup truck waving a pistol at strikers on his land," reported Texas Monthly. ${ }^{4}$ The Valley Morning Star claimed that Brand did not actually "leap out" of the vehicle but did draw a pistol. "There's an injunction against these people and if the police won't move them off my land, I'll move them off," he reckoned. ${ }^{45} \mathrm{He}$ later boasted that "I'd do it again today." He reasoned that "a bunch of people out there with rifles and sticks" were threatening his family, his workers, and himself, and that under such circumstances he would stand firm. ${ }^{46}$ When onion workers struck against another grower in nearby Raymondville in 1979, "Brand marched in with his own workers and harvested his part of the crop, crippling the strike." 47

As the mayor of McAllen in 1978, Brand again demonstrated his toughness when Anglo farmers from the Midwest and South converged on the International Bridge in Hidalgo, south of McAllen, to protest the importation of Mexican produce, which, they claimed, constituted unfair competition and contained banned pesticides. Although Brand himself prompted the protest by publicly admitting that he had himself imported such crops, he and other officials dispatched a hundred officers, mostly from McAllen, who lobbed tear gas canisters and clubbed farmers within " 15 seconds" of engaging them. The officers arrested two hundred farmers and sent some of them to the hospital. Brand arrived after the "arrests and claimed farmers had violated their agreement to protest peacefully for only five minutes." When the farmers denied that they had made any such agreement, he retorted that their word was not "worth a plug nickel." As officers herded the farmers onto buses, "trucks loaded with Mexican produce began rolling past-less than 50 feet away." 48 Shortly thereafter, the McAllen city commissioners unanimously passed a resolution-introduced by a councilman who was "a lower Rio Grande valley grower, and supported strongly by Mayor Othal Brand"-which commended the police force for its methods. The resolution won unanimous approval. ${ }^{49}$ 


\section{MPd Police Scandal}

During Brand's tenure as mayor, the MPD earned a reputation for violence toward working-class Mexican Americans, although the evidence suggests that this misconduct was well established much earlier. "During the last five years, numerous suits have been filed against the McAllen police charging brutality and undue force," reported the Dallas Morning News in March 1981. "In the last year alone, the City of McAllen has paid $\$ 400,000$ in settlements or judgments on those suits—an average of $\$ 5$ for each citizen." 50 Harrington, the ACLU attorney, charged that "the City of McAllen has a long history of police misconduct, that city and police officials knew about it and that they failed to take steps to correct it." 51 There was "a custom in McAllen of police misconduct," he argued, and, although this "'custom' wasn't in writing, 'it was just as strong and had as much force as something in writing." " 52

In many instances the offending officers-Anglo and Mexican American alike-were the aforementioned members of the self-proclaimed "C Shift Animals." They were so confident of their right to perpetrate these offenses that they did so in front of a video camera posted over the booking area. Once publicly released, the videotapes showed that "the men on $\mathrm{C}$ shift, in a systematic pattern during the last six years, had beaten, kicked and abused prisoners in their custody for no apparent reason." One of the tapes "showed an officer beat and pummel a prisoner, then grab him by the hair and smash his face repeatedly into the booking desk." 53

In subsequent court proceedings, officers flatly denied that they were responsible; they testified instead that they were "trained to 'get even' with prisoners who dished out verbal or physical abuse." A sixteen-year veteran and "former commander of the late-night ' $\mathrm{C}$ ' shift" told the court that his officers " 'exiled themselves from the community,' and abuse became a trademark of their exile. He said officers on the shift had earned a bad reputation." In addition, he admitted the impact of this culture on new officers. "A lot of officers took action out of peer pressure-you must do it to belong." 54 Another witness testified that an officer who trained new recruits told them "to 'throw (your) weight around as much as you like,' and 'if an ol' boy falls and busts his face on a curb, well, that's just too bad.' "55

In addition to these beatings, MPD officers committed other violations. One testified in court that "the telephone prisoners used to call their attorneys is tapped and the conversations are recorded," a procedure 
that a disgusted observer called "a gross indiscretion and illegal as it can be." ${ }_{6}$ In an incident captured on video, officers told a man arrested for drunkenness in 1979 "that officers would keep a marijuana cigarette found on the suspect and charge him only with intoxication." On the video "the men talk about the cigarette. Then one of the officers tells [the prisoner] 'We'll just keep the grass and charge you for DWI (driving while intoxicated)." " Not surprisingly, the records clerk could find only the DWI charge and no record of the marijuana; the officers had not placed the drug into evidence, suggesting that they may have smoked it themselves. ${ }^{57}$ In an incident in 1978, an officer "allegedly took a prisoner to a flower bed in the rear of headquarters... and stomped the individual." At the time the officer involved was slated to "be promoted to lieutenant in charge of traffic." 58

In addition to the beatings, internal documents suggest that some officers engaged in sexual offenses against those whom they were supposed to protect. One patrol officer "spotted a couple making love in the back seat of an automobile," noted a 1978 memo:

The officer walked up to the couple with a flashlight and made the nude male stand in front of the vehicle lights. He then entered the vehicle and asked the nude female to open her legs to search for evidence. He refused to let the female put on her underwear and confiscated the underwear as evidence. (The evidence and unfiled reports were supposedly found in [the officer's]...P.D. locker.)

On a second incident, the same officer stopped a female on a D.W.I charge. The officer supposedly offered to follow the female home. The female got into the car and a high speed chase ensued into the City of Pharr. The female was handcuffed and the tube-top blouse she was wearing was down around her waist. She has allegedly complained that the officer had no right to fondle her breasts after removing her blouse. 59

Critics charged that Mayor Brand was "aware as early as 1977 of widespread brutality by McAllen police."60 Furthermore, in a 1978 memo, Officer Gary Miller wrote that "on or about July 24, 1978, Ruben De Leon, Don Herzing and myself" met with high-ranking city officials to discuss "what we felt were problem areas in the McAllen Police Department," problem areas that included the beating of prisoners. ${ }^{61}$ Amid a flurry of court cases in 1980-1981 in which he successfully represented twenty-five of the twenty-six plaintiffs, Harrington indicated 
that "Brand had testified that he knew of the existence of the videotapesinstalled by the department to monitor the booking-desk area-and what they showed 'as far back as 1977.' " A year later, he charged that seven officers met with the mayor "to inform him of misconduct by fellow officers." Harrington reported that "in 1979, the mayor also told a supporter who complained about the treatment of a prisoner that he had viewed videotapes taken at the police station." Democratic state senator Hector Uribe alleged that officers had officially informed Brand of the brutality by officers in 1978. Uribe indicated that he was “ 'extremely concerned' about reports that private telephone conversations between attorneys and their clients were tape-recorded by police and that Brand had ordered videotapes of the beatings erased." 62

In McAllen influential people expressed their concerns over the negative press and the potential blot on the city's good name. "The tarnished image of the McAllen Police Department is going to take a long, long time to be erased," lamented the Monitor. "Lengthy stories of misconduct by some members of the department have been given extensive coverage" around the state and country. "The impression given, of course, is that McAllen policemen, as a whole, are a gang of heavyhanded dispensers, of not only the law, but punishment too."63 A disgusted resident of Edinburg, named Al Ramirez, slammed the press for its concern about reputation and its evident lack of concern about justice. According to Ramirez, one public commentator "tearfully related how sad it was that McAllen's reputation had been smeared nationwide 'since the area is so popular with tourists from all over the country.' Yes, that's what he said. In other words, it's SAD because it might [a]ffect the local economy, the way Miami has suffered, but not SAD because improperly supervised policemen systematically and consistently violated the rights of citizens." 64

Although some McAllen residents had been aware of the police violence since the mid-1970s, Harrington was the one who brought its magnitude to light. A native of Michigan, he met and married Rebecca Flores while both were students at the University of Michigan. "His wife, who grew up in Texas," was the director of the United Farm Workers union in Texas, "and he is the union's lawyer," reported the Washington Post.65 After nearly five years of litigation, he secured and introduced into evidence in March 1981 eleven of the jailhouse videotapes, containing nearly an hour's worth of footage. Recorded over six years, these tapes revealed dozens of beatings by police officers and a general disinterest 
among their peers to curb this misbehavior. "They just stood around, watching the beatings or patiently worked on their reports, just like nothing was happening. That's truly an appalling thing." Soon, reporters gained possession of the tapes and Harlingen's KGBT "ran the tapes unedited, showing the scale of abuse and the often harsh and profane language used by police." 66

Many Anglos-and more than a few Mexican Americans-stood behind the department. "The issue of 'police brutality' seems to be getting driven into the ground," a resident wrote to the Monitor. ${ }^{67}$ Another condemned those who criticized officers, no matter their crimes. By demanding a higher standard of conduct, he believed, critics aided and abetted criminals. "If we think we have problems now with burglaries, hold-ups and other violent crimes, just wait until it becomes generally believed throughout the U.S. and Mexico that, in McAllen, the police are restrained from using force in making arrest. That if they do, such action can be construed as 'police brutality,' entitling the 'victim' to the services of an eager-beaver civil rights attorney." He added that the imposition of constraints on the officers would "be a clarion call to all the thieves and thugs north and south of the border to come to McAllen to ply their trades." 68 Yet another opined that "the crimes committed during the hours that ' $\mathrm{C}$ ' shift is on duty are usually committed by the dregs of society, drug pushers and addicts, alcoholics, bums, juvenile delinquents, prostitutes, etc." 69

However, many Mexican Americans and some sympathetic Anglos protested the violence. Harrington observed that the brutality was not new; what was new was the evidence to prove it. In five years of filing suits, he said, "no one believed us until they saw the videotapes."70 In a letter to the Monitor a police critic avowed that "McAllen must rise in one loud indignant voice, and demand that the actions recorded by the police department's own camera be stopped." He added that "we are not living in Hitler's Germany nor Communist Russia and our police must not be allowed to act as if they were."71 Speaking in Dallas in his last official act, Ruben Bonilla, a prominent civil rights leader and the outgoing president of LULAC, spoke out against the McAllen police and its officials. "In a fiery farewell speech," he "lashed out at recently re-elected Mayor Othal Brand of McAllen" and called him "a 'bigot' and a 'racist.' "72

For their part, police officers-including the many officers and administrators who had played no role in the abuse-suffered a blow to 
their morale. "An outsider can feel the tension just standing in the [police department] lobby," observed the Monitor on April 27, 1981. "Behind the scenes it's even worse." With the public clamor over the scandal "and the publicity about civil rights of prisoners, many officers feel another set of civil rights have been overlooked-theirs." Following the release of the tapes, several investigations, a series of resignations by administrators, a steady drip of embarrassing revelations, and the opening of rifts within the department, many officers felt trapped. "Right now you just get by," one told a reporter. "You do your job and go home, and you don't make any waves."73

In November 1981 the Dallas Morning News reported that the federal grand jury in Brownsville had completed its investigation and indicted several former McAllen officers-Anglo and Mexican American-on civil rights charges. In addition, the Newsindicated that the "Justice Department is also said to be investigating whether city or police officials tried to cover up the allegations of brutality, and whether tapes protected by a federal court order may have been destroyed."74 During the 1982 trials federal prosecutors revealed some of the sordid details of the violence unleashed against a number of prisoners by McAllen officers, including the excuse proffered by a reluctant participant in the beating of a Mexican American in custody: "You beat him. I can't. I have too many lawsuits pending."75

\section{The McAllen Municipal Election, 1981}

Even before the release of the MPD tapes, a coalition of Mexican Americans organized to challenge Othal Brand in the 1981 municipal election and to elect the first Mexican American mayor in the city's history. They began their work in January 1980 when McAllen officials announced a plan to sell the McAllen General Hospital and to "let a private company build a replacement before the hospital becomes a 'taxpayers' burden.' " Opponents argued that the agreement would reduce indigent care and "force many paying patients to use other hospitals after an expected increase in room rates and fees." With many impoverished residents (mostly Mexican American), they quickly realized that they would not be able to afford a private facility because "this is a chronically depressed economic area." Those lining up against the sale represented "poor Mexican-Americans of the area who would have to seek medical help elsewhere for non-emergency cases." The Dallas 
Morning News added that this "issue is one of the touchiest to divide this border city in years." 76

Concerned over the threat to indigent care, Mexican Americans launched a "massive voter registration drive" among poorer south side residents. Jerry Polinard, a political scientist from Pan American University, concluded three years later that "Voting in the ' 80 s has been along ethnic lines...pitting the Hispanic south side against the north." When politicians decided to hold a referendum on the hospital issue in 1980, 6,500 additional Mexican American south side residents registered and defeated the plan. "It was classic," Polinard stated. "Since McAllen is roughly 70 percent Mexican-American, the south side discovered the importance of voter registration." 77 The Monitor shared Polinard's assessment. "This was the most highly organized city election campaign in history," it observed after the 1981 vote. "Both sides organized down to the city block level to turn out the vote in an effort comparable to that undertaken in presidential elections." 78

Once they had defeated Brand and his allies on the hospital issue, the Mexican Americans targeted the twin objectives of defeating the incumbent and electing one of their own in the mayoralty election. In the so-called post-civil-rights period, they rankled over the racism that continued to define the social order and grumbled that the Anglos, though no longer expressing as much overt public racism, still regarded them as incapable of governing. "The fact is that Mexican-Americans in this city, as in almost every city in the Valley, have been excluded from the decision-making, political process," a prominent Mexican American told the Dallas Morning News. "What is more, this exclusion has been by design, not by default." In essence, Mexican Americans largely believed that "racism....is McAllen's main political issue. And racist attitudes have infused local politics."79 César Chávez himself credited the hospital effort as the catalyst for Mexican American activism in the city. Speaking in San Juan, he pointed to the "defeat of a referendum to allow sale of McAllen General Hospital as a 'first trial run at political activity.' " Mexican Americans " 'opposed the sale of the hospital and WE were victorious. We took on the establishment and won,' he said." 80

In January 1981 local farmworkers began a strike against citrus growers. At that time they earned only $\$ 2$ an hour. A union leader set forth their demands. "The farmworkers want a guaranteed 8-hour work day, wages of $\$ 10$ a box for oranges and $\$ 8$ a box for grapefruit. They also demand fresh drinking water and toilets in the groves." Two weeks 
into the strike they targeted McAllen mayor Othal Brand because of his efforts to curb their activism. "Eleven Texas Farmworkers Union members barricaded inside the office of McAllen Mayor Othal Brand vowed Friday afternoon to spend the weekend there to protest the mayor's refusal to discuss their citrus strike." He refused to meet with them. Instead, with what one imagines as a wink and a nod, he claimed that he was only mayor and had "never been a spokesman for the citrus industry." 81 With his rebuff, the farmworkers and the residents of the "Hispanic south side" who had defeated the hospital referendum earlier found a further common cause in defeating Brand in the mayoral race.

For their part, Brand and his supporters, other agricultural interests, and many middle-class Anglos (as well as some Mexican Americans) rejected the charges of racism and attributed the ethnic peculiarities of the local power structure to ostensibly race-neutral-but deeply racialized-issues like hard work and know-how versus sloth and ignorance. A prominent Anglo refused to give his name to the journalist who interviewed him but he certainly embraced the views of many: "McAllen is the best-run, cleanest, most attractive city in the Valley. It's the city tourists remember and want to visit again. And it's no coincidence that it's run by an Anglo government." 82 As suggested by his refusal to lend his name to this sentiment, most Anglos had by the early 1980s internalized the color-blind discourse which came to dominate popular American discussions of racism by the mid-1960s.

Reflecting this color-blind discourse, proponents of it were eager to distance themselves from the "racism" which they defined narrowly as the avowed bigotry and overt discrimination curbed by the Civil Rights Act of 1964 and Voting Rights Act of 1965. Assuredly they did not regard racism as structural, a system wherein resources and opportunities flowed toward Anglos and away from minorities through a process of unearned advantage. In declaring support for Brand, they were eager to affirm that their decision reflected his ideas, not his race. "Let's be positive and realistic," one declared, "and if the person we need to elect for our own benefit is a Negro or Chinese, we must vote for that Negro or Chinese, without taking [into] consideration ideology, race, or color, but only considering who is the most qualified to occupy that position so that our family can live in a more dignified way." Lacking the requisite Negro or Chinese, he endorsed Brand.83 Another Brand supporter articulated her color-blind bona fides. "I don't care if the mayor of McAllen, the city commissioners, etc., are Mexican-Americans, white, 
black, or green with purple polka dots! I want what's best for McAllen, its citizens, its future. I want to vote for that man, whatever his color or race!" 84

The south side coalition selected as its candidate Dr. Ramiro Casso, a leader in the fight against the hospital sale. The physician was a recognized civil rights advocate devoted to the welfare of the most oppressed. "Casso, 58, has spent much of his medical practice among the poor and was honored [the day before the election] by the Texas House of Representatives for his work among lower-income families," reported the Dallas Morning News. 85 Casso had never held office "but a victory.... as the first Hispanic mayor of McAllen could put him in the limelight of Mexican-Americans gaining political power in the Southwest." Casso urged the "Hispanic population of McAllen to turn out in force," charging that Brand ran "a government by the iron fist-government by intimidation." 86

When the police scandal broke in late March 1981, Brand was in a four-man election fight in advance of an April 4 ballot. On March 29 the Monitor addressed the impact of the scandal and his alleged role in it. "During this current controversy, the big questions-shades of Watergate-are whether or not city officials knew that a pattern of abuse to prisoners was going on and whether there was an effort to cover-up the wrong doing," it mused. "The answer to either is difficult to determine." 87 Based on the evidence, Brand had known about the abuse since 1977 but had done little to stop it. Furthermore, he had attempted to tamper with the evidence. On March 25 an official testified that Brand had ordered him to destroy the videotapes. The official then added that "the tapes were preserved because he checked with the city attorney who told him to disregard the order." The same witness recalled that the mayor worried that "there may be some things on there and he was most adamant about them being erased." 88 On March 26 Brand testified and, even though he dutifully condemned the beatings, he hinted that the suits were frivolous. "Brand wore a campaign button into the courtroom but took it off before he took the stand. While on the witness stand, he kept toying with his watch, and he gave long, repetitive answers to many of Harrington's questions." Eventually, the judge "told Brand to 'just answer the question without a speech.' "89

In the days immediately preceding the election, Brand was limping toward the finish line. To make matters worse, the mother of a youth beaten by officers asked Governor Bill Clements to withdraw his recent 
nomination of Brand to the board of the Texas Department of Corrections, the agency that supervised Texas prisons. ${ }^{90}$ Clements refused to do so a few days later, declaring that he would not pull Brand's name until he knew more details. After all, he added, the mayor was "a very patriotic American and a great Texan and a friend of mine." 91 Within a few weeks Brand saw his nomination defeated, with the reelection fight and the expanding police scandal significantly damaging his candidacy. 92 As the Monitor observed, "Probably Brand should have seen the writing on the wall, and declined the governor's nomination. But as we said before, the mayor is a fighter." 93

After the vote on April 4 Brand claimed that "I've never seen the ugliness before that I saw in the election today.... I never expected anything like this. My home was besieged by threatening calls and apparent attempts at entrapment." He also claimed that he had been surrounded at a polling place by Mexican Americans angry over police violence. ${ }^{94}$ For their part, Mexican American voters reported that they had suffered intimidation in their efforts to vote. "Voter Juan Mena," Election Inspector John Lovelady observed in his report, "was told by one of the clerks ' $\mathrm{Si}$ no sabe leer y escribir ingles, que esta hacien aqui.' (If you don't know how to read and write English, what are you doing here.) Mr. Mena was going to leave without voting. One of the watchers observed this and brought it to the attention of Mr. Arce. The judge (Arce) got Mr. Mena to come back and vote." 95 Cary Hatch, another election inspector, wrote that a voting "Judge was having trouble with his voting booth attendants; who were rushing and generally bullying the voters if they did not vote quick enough; these attendants would frequently enter the booth while a vote was being cast to hurry the voter along." 96

While no candidate won the election outright, Brand and Casso emerged as the runoff candidates. Mike Frost finished third and, suggesting the preference of the "establishment" for an Anglo maverick over a Mexican American, he threw his support to Brand. 97 " ' $I$ 'm going to support Mayor Brand 100 percent in the run-off in any way I can,' he added. 'He is by far more qualified than Dr. Casso, who's not qualified at all. I think my supporters will assist the mayor too.' "98

At a campaign event after the first election Brand (along with the Monitor) explicitly noted the coming together of Anglos and the exact opposite between many Anglos and Mexican Americans. "Noticeable in the crowd was the number of former supporters of Commissioner Mike Frost, who was eliminated," the Monitor noted. "Mike and I are better friends than 
we ever were," Brand stated to thundering applause. The mayor noted that there was " ' $a$ division occurring in our city I don't like to see, ....charging that 'outside forces are at work within our city trying to gain control.' " A Mexican American Brand supporter told the crowd that the "Casso forces have been harassing and influencing our youth with hate." 99

With a runoff election set for May 10 between Brand and Casso, the candidates jettisoned even the pretense of substantive policy stances and embraced a divisive, no-holds-barred slugfest fraught with "ethnic overtones." 100 Not surprisingly, Casso hammered away at the police scandal, Brand's involvement and, allegedly, his cover-up efforts, and situated all of these within the context of racism and classism. "Brutality has not completely stopped," he declared. "Othal Brand has the power to stop it, but he hasn't." These beatings, he added, had received national attention thanks to the video footage which aired on television. With some exaggeration the physician claimed that the tapes had "given the city a bad name as the police brutality capital of the world."101 On another occasion Casso charged that Brand had "failed as mayor by allowing problems to develop in the police department and by governing in a divisive, intimidating manner." 102

At the same time, Brand and his supporters charged that Casso and his surrogates colluded to ensure the release of the tapes to the media as a means of damaging the incumbent. Brand noted that most of the taped beatings occurred between 1974 and 1976 "and 'it just happens to come up now.' "103 Although their claims are easy to understand in light of the political fight in which they were engaged, the federal judge in the case favored full disclosure. Judge James DeAnda, hearing the evidence on March 24, stated that the public should see the tapes when, from a courtroom in Brownsville, he denied a motion by the City of McAllen to bar their release. "They (the videotapes) are evidence in this case and a public trial is fundamental in this country," he said. "I don't intend to try... this privately. I don't think I can."104

Given the reputation of the Onion King as a man who, as Mr. Agribusiness and as mayor, had done everything he could to stymie unions, Casso and his campaign had little difficulty in portraying Brand as a representative of Anglo repression. Many Mexican Americans shared the view, later expressed by a civil rights leader, that Brand had run a "racist campaign" typified by both racism and classism, and exemplified by endemic violence against the Mexican Americans. Many of them believed that Brand had made "McAllen 'the laughing stock of the Valley.' "105 As 
the campaign got into full swing, Brand supporters took issue with such charges. One fumed that "I hear more and more charges of racism being leveled against our incumbent mayor."106

In a further indication of the degree to which the color-blind discourse expanded into the vacuum left by the collapse of overt racism, many Anglos - choosing to forget their sustained and long-standing discrimination against Mexican Americans-decried Mexican Americans for being racist by raising the issue of historical inequality. In the Monitor a Brand supporter castigated Casso for stirring up "ill-feelings between Mexican-Americans and Anglos," which, he believed, would profit from a period of benign neglect. In an instructive twist he posited that race-obsessed Mexican Americans would metaphorically lynch an innocent Anglo at the altar of their invented suffering: "Don't try to hang Othal Brand."107

Yet, Brand continued to validate Casso's charges. As the Washington Post observed, he had recently attempted to overload the Human Relations Board-intended to mediate inter-racial difficulties - with fellow Anglos. "In appointing members of the human relations board this spring," it observed, "the city disregarded court requirements that the board represent the economic and racial makeup of the city. McAllen is 71 percent Hispanic and has one of the lowest per capita incomes in the country, but the city attempted to fill its three slots on the fivemember board with Anglos." The Post added that, "under threat of contempt of court, the city altered its nominees."108

By hammering the linkages between the physician and the United Farm Workers and other civil rights and leftist organizations, Brand and his supporters assisted Casso in his charges of racism. Brand told listeners that "Casso's campaign was controlled by the United Farm Workers and other outside groups." 109 Although Casso and his supporters controlled their campaign, they did in fact have strong links to rural Mexican American laborers and the unions that fought for them. "About 1,000 members and supporters of the United Farm Workers" gathered in nearby San Juan in early May to demand economic justice for agricultural workers and pass a resolution commending Ramiro Casso for his "dedication to the cause of the poor people." 110 With allegations of "outside influences" attempting to "take over" the city, and with predictions of an impending revolution, Brand's reelection campaign reinforced his message with his supporters. "Anyone can readily see who is backing, supporting and organizing the campaign of Doctor Casso," it blared. "Is this what you want controlling your city government? Their sights are set on McAllen. 
No one can imagine the far-reaching implications that such a takeover would have on our city." 111

Brand was so successful in painting his opponent as a revolutionary that Casso soon found himself responding to the following question: "Is it true that you intend to have a 'Mexican take-over' of City Hall?" That, Casso replied, "is a false rumor." Brand, he added, was spreading rumors "to scare people into believing that an anti-Anglo take-over is about to take place." According to Casso, his campaign had downplayed the "ethnic issue" but his "opponent wants to make an issue of Mexicans vs. Anglos, because he feels that it is to his political advantage." Brand, he charged, "confused criticism with racism. He thinks that anybody who dares to challenge him is divisive and backed by outside influences. If his opponent is Spanish surnamed, then he is by Brand's definition, a 'racist.' "112

Underscoring the physician's claims, Brand charged that Casso-who advertised heavily on Spanish radio-used "the Spanish broadcasts to muddy the race." The Mexican American candidate "doesn't dare to do that in English" because, Brand claimed, "Casso appeals to racism through his Spanish advertisements." 113 A Brand supporter placed the blame for the racialized discourse at the feet of the challenger. "To simply charge that Mayor Brand is a 'racist' is actually quite humorous when one considers the colorful aspersions being cast by some of his critics," she wrote. "Smacks of a little racism (actually, a great deal of racism), wouldn't you say?" Anticipating that Casso supporters would claim that only Anglos could be racist, she added: "Or doesn't racism make a full circle?"114 Another Brand supporter questioned the use of Spanishlanguage advertising at all, notwithstanding the large Spanish-speaking population. "Are we in Mexico-can't they speak English??"115

Casso may have appealed to racial solidarity on Spanish radio but the evidence suggests that Brand supporters greatly exaggerated the matter. In one instance Casso supporters issued an advertisement urging Mexican American migrant workers to vote by absentee ballot prior to their departure and incentivizing that request with a photograph of a Mexican American youth and the emotive caption, "La Esperanza del Futuro" ("The Hope of the Future"). A Brand supporter, however, provided an alternative and entirely disingenuous translation. "Just this week, I saw an ad in a Spanish language newspaper which pictured a young boy and the words...'This boy has no chance in life if Othal Brand is elected Mayor.' I am appalled at the picture being painted of Othal Brand as a brutal and heartless man."116 
Days before the initial election in April, Brand had charged that he and his supporters had uncovered "large-scale voter registration fraud" in the city, "including registrations by residents of Reynosa, Mexico, just across the U.S.-Mexico border." Notifying the Federal Bureau of Investigation (FBI) and the Texas secretary of state, Brand told reporters that a computer cross-check showed five hundred duplicate listings. "I don't think we've scratched the surface," he said. The mayor claimed that he had found the irregularities months earlier but had hesitated to make the charge. "I didn't want to polarize the community," he asserted. "But I wanted to send a message to the people of McAllen not to vote illegally. What we want is a clean election." 117 Warning that offenders would be charged with a felony, he called for "a 'purge of the rolls,' and state legislation to provide more safeguards." 118

Not surprisingly, Casso and his supporters contended that Brand's accusations were "a campaign ploy and [that the] rolls are properly constituted." 119 Nonetheless, both the state and federal governments decided to dispatch election observers to monitor the vote. Undermining Brand's charges of widespread fraud, both the Texas secretary of state and the Southwest Voter Registration Education Project (SVREP) concluded that there had been no fraud during the April 4, 1981, municipal election. In its press statement, the SVREP declared that "the vast weight of the data leads us to the inevitable conclusion that Mayor Brand's allegations are a shameful attempt to appeal to the worst elements in Texas politics. The allegations and hysteria raised by Mayor Othal Brand are clearly designed to intimidate Mexican American voters from participating in the electoral process." There was, it emphasized, "no fraud committed." Given what it saw as Brand's intimidation tactics, it added that "we have asked the Department of Justice to send Federal observers to McAllen to insure the integrity of the vote in the May 9, 1981 run-off." 120

Two days before the runoff election, Brand and Casso clashed in a televised debate where "charges of racism and dirty politicking were exchanged by the two candidates for mayor." Interestingly, each pointed to intermarriages within their families as evidence that they were "untainted by racism." Brand repeated his charges that Casso appealed to Mexican Americans on racial grounds in Spanish-language advertisements. Casso denounced Brand for "false charges of racism and unionism," and charged that the incumbent injected racism into every aspect of the voter drive. "At the outset of the campaign," the physician argued, "I ran ads 
imploring all candidates to refrain from using ethnic references' but Brand's ads 'talk about Anglo versus Mexican-American.' "121

Numerous sources reference the frenzy in McAllen in the days beforeand particularly on the day of - the election. "Never have there been such hassles over the conduct of the election," reported the Monitor, citing numerous instances of disputes between election judges and poll watchers over absentee ballots. "In fact, never before have there been such crews of poll watchers. Schoolhouse polling places, inside and outside, will be thick with them Saturday. Pressure was so heavy on election officials that the absentee judge quit midway in the voting period and was replaced by another." 122 The Monitor reflected on the tension. "Is this the most heated, hard-fought election in the City of McAllen's history? someone asked the other day. Indeed, it is...[a] frenzied atmosphere in the city." 123 On May 8 the Monitor reiterated that the "most hectic local election campaign in the history of McAllen will reach a climax...when thousands of voters participate in [the] run-off." 124

On May 10, Election Day, the tension exploded. A scuffle arose at one polling place "in the early afternoon when someone threw a stick at another trying to tear down campaign signs," noted the Monitor. "In the ensuing melee one participant's face was badly cut. The affray brought police officers and an ambulance." At another polling place an official requested that an officer be posted to prevent unrest. Elsewhere, officials and observers reported that supporters for one candidate or the other were blocking entrances to polling places. Around the city supporters using trucks with campaign signs and sound equipment rallied supporters, "honk[ing] their horns long and loud." Brand himself claimed that farmworkers surrounded him, calling him "Brand, the Nazi." 125 In his comments on the state officials dispatched from Austin to oversee the vote, Casso claimed that "there was an intimidating effect from the staff members from the Secretary of State's office, sent by [Governor] Bill Clements to help his buddy [Brand] down here." 126 According to a report in the Washington Post, Brand "used cameras from his company to photograph voters on Election Day. He says he did it to obtain evidence of vote fraud, but Mexican Americans believe he was trying to intimidate uneducated, inexperienced Hispanic voters." 127

When the vote tallies rolled in, Brand defeated Casso 8,729 to 7,847. Although the election reflected racial division, an unknown number of Mexican Americans sided with the incumbent, a fact Brand emphasized. "We had enough cross-over vote with all the ethnic overtones in this 
campaign. We had enough cross-over from the Mexican American community to help us and put this town back together." 128 In fact, in a report published on May 24 the Monitor found that the vote was "Not on Ethnic Lines." It concluded that "about 8,769 of the 16,632 voters who participated were Spanish-surnamed and about 7,863 were so-called Anglo American. Brand claimed Spanish support, and he had it, in sufficient numbers to give him an edge." 129 Yet, the newspaper's report did not accurately reflect reality - the 1981 political campaign, intertwined as it was with the MPD scandal, ripped McAllen apart along racial and class lines.

The ugliness of the political race climaxed in its aftermath. "A mudslinging mayoral race has come to a bitter end with the loser denouncing Mayor Othal Brand...after the incumbent won re-election despite allegations of racism and covering up police brutality," wrote reporter Susan Stoler. In a speech to his supporters after the votes rolled in, Casso roared: "Anybody that resorts to racial hatred to win an election is the scum of the earth." The next day, Brand retorted: "I'm just glad we won after having seen my opponent on television after I came home last night. Thank God we won." Noting that so heated a campaign was something of a novelty, the Oregonian mused that the "candidates exchanged charges of racism and gutter politics in a city accustomed to quiet, polite campaigns." 130 Polinard, the political scientist, later recalled that the " '1981 mayoral election was the dirtiest campaign I've ever seen, including those I've studied in Louisiana'....Fear tactics and an us-againstthem attitude underlie all the campaign materials and ads." 131

The McAllen election - and the mobilization of working-class Mexican Americans as a voting bloc-attracted the attention of observers across the state and throughout the country. However, it seemed to irritate William Murchison of the Dallas Morning News. Apparently suffering from amnesia about either the Jim Crow which had governed Texas until the mid-1960s or the persistence of intra-racial voting patterns among Anglos thereafter, Murchison concluded that the enthusiasm of Mexican American voters for a Mexican American candidate for "racial" reasons was sufficient proof that the 1965 Voting Rights Act should be repealed. "America's media have discovered that next year the Voting Rights Act expires, unless Congress steps in and renews it," he wrote on May 28. "This has undammed a spate of dewy-eyed articles, such as John Crewdson's recent 3-hankie vignette in the New York Times, wherein the Voting Rights Act is credited with the enfranchisement of Dominga Sausedo, McAllen, Tex."132 
Noting that Sausedo would not have been able to register or cast her first ballot without the protections of that law (including its protections for non-English speakers), Murchison wondered if it "would be so bad a thing" if she remained voteless. "When [Crewdson] asked Mrs. Sausedo to explain her vote for McAllen mayoralty candidate Ramiro Casso, "her only answer was that he was "Mexicano." " Since it had been sixteen years since the anti-black police riot in Selma, Alabama, which brought about the Voting Rights Act (expanded to protect Mexican Americans in the Southwest in 1975), the News writer viewed that as sufficient and then concluded with the following: "A decade and a half is long enough to punish and browbeat a whole region. The Voting Rights Act must die." 133 Like many Anglos Murchison had internalized color-blind discourse and now regarded any reference to race or racism — even among those who had been its victims for decades-as an act of racism. Accordingly, he now regarded the Anglos in Texas and across the South and Southwest as racism's most recent victims.

In a tragic conclusion to the tumultuous spring of 1981, a burglar, Raymond Beasley, in McAllen killed Officer Rosalin Suarez Jr. during an attempted arrest, bringing "a flood of sympathy calls to a force deluged all spring with outrage over the brutality tapes." 134 Not surprisingly, many of those whose sympathies had always been with the officers used the killing as a springboard to attack Harrington and the Mexican Americans who had been the victims of the police. "On Wednesday, May 20, 1981, Jim Harrington had the gall and audacity to broadcast on television that he was sorry for what had happened to Suarez," wrote an observer in the Monitor. "Harrington, you are just as much a part of CAPITAL MURDER as the suspect.... You've destroyed many police officers' lives already by continuing to intimidate innocent police officers who supposedly beat innocent (?) Mexican Americans. Have you ever thought of defending an Anglo, Harrington?" She added that "as far as you [Harrington] are concerned all ignorant, radical, uneducated, longhair, tatooed [sic] Mexican-Americans should be allowed to rob banks, commit murder, rape and kill children, and abuse and kill police officers." 135

Despite the voluminous evidence, jurors acquitted all of the accused officers at trial. Victims and their sympathizers reacted swiftly. "Two dozen plaintiffs have filed civil rights suits against McAllen police, protesting the recent acquittals of three former officers on civil rights charges," reported the News on February 22, 1982. Harrington, too, 
expressed disbelief in the verdict: "Make no mistake about it, it was an injustice." 136 Mexican Americans and their allies protested. "An estimated crowd of 450 persons took to the streets of McAllen Sunday afternoon in a 'March of Solidarity' against injustice and police brutality." Reflecting, perhaps, the recent killing of Officer Suarez, the organizers stressed that they desired a nonviolent protest against police violence rather than police officers. Also eager to avoid violence, MPD officers hung back, dispatching only a handful of plainclothes detectives to disperse discreetly among the marchers. The Monitor observed that some Brown Berets, a Mexican American organization which promoted armed self-defense, were at the event "in a minor show of force. Dressed in the traditional brown uniforms and brown berets, all five ministers of the South Texas delegation were present as security for the gathering." 137

\section{Conclusion}

Like their counterparts across Texas, McAllen officers routinely assaulted Mexican Americans in the 1970s and early 1980s; unlike their counterparts, those in McAllen were so confident in their right to commit these crimes that they perpetrated them in front of a video camera that recorded them. Although virtually every victim was a working-class Mexican American, the officers, Anglo and Mexican American alike, shared the implicit view that the prevailing racism and classism provided a shield against public condemnations or legal repercussions. In their assumptions they proved correct, not only over the years of documented abuse but in the acquittal of every officer implicated in the beatings and documented on video. Although violence by local police was crucial to the enforcement of Anglo supremacy, scholars have focused narrowly on the murderous actions of the Texas Rangers in the 1910s and on the practices of immigration authorities on the border. Among its findings, therefore, this study demonstrates the need for a greater emphasis on the issue of police brutality, particularly at the local level, throughout the twentieth century.

The events in McAllen highlight the complexity of social relations in South Texas in the post-Jim Crow period. They demonstrate that Anglos retained a lock on political and economic power and continued to oppress Mexican Americans. They demonstrate, too, that more than a few middle-class Mexican Americans shared not only Anglo contempt 
for those Mexican Americans who occupied the lowest economic strata but also solidarity with the officers and the mayor. These events also show that working-class and some middle-class Mexican Americans forged a political alliance in these years based on their opposition to racist oppression and they nurtured it over the next two decades until it bore fruit in 1997 with the election of Leo Montalvo, the first Mexican American mayor. Finally, the events exemplify how Anglos couched their continued dominance in the emerging color-blind discourse that spread across the U.S. in the 1960s by supposedly transcending racism and privileging only merit, and by actually accusing the victims of racism with racism for elevating the issue as a matter of public debate.

With its emphasis on the business and political life of the Onion King, this study builds on the work of historians Timothy Bowman and John Weber, who explore the rise of powerful, large-scale agribusinesses in South Texas in the twentieth century and their development of racist labor practices-including the exploitation of undocumented Mexican immigrants - which eventually defined the region and spread across the rest of the country. Given Brand's lengthy and controversial tenure as mayor, it provides a preliminary assessment of some of the volatile political issues faced by him in the final decades of the twentieth century. Given his extraordinary influence on South Texas and his complex legacy, Othal Brand merits an exhaustive scholarly investigation.

This study contributes to the scholarship on the Mexican American civil rights movement of the 1960s and 1970s, and demonstrates that in McAllen, at least, it gathered steam in the early 1980s as residents came to recognize their political power, first through their resistance to the privatization of the hospital and then through their mobilization against the reelection of Mayor Brand. As other historians have concluded, Mexican Americans engaged more narrowly in political activism by the 1980s rather than in the mass protests of the late 1960s and the early to middle 1970s. 138 Nevertheless, as late as 1982 hundreds of Mexican Americans and uniformed Brown Berets could still mobilize for such a march.

Finally, the study demonstrates the significance of the Voting Rights Act-expanded in 1975 from the Deep South states to the Southwestin ensuring that Mexican Americans could mount their challenge to the Anglo establishment in the first place. "McAllen, Texas, may be the best place to start the debate on renewal of the Voting Rights Act," declared the Wall Street Journal after the runoff. "The runoff could have been scripted by a liberal screenwriter: Othal Brand, the incumbent mayor of 
the scandal-plagued city with the nation's lowest per capita income, is an Anglo millionaire, the largest vegetable grower in Texas." His challenger, Ramiro Casso, was a Mexican American "supported by local activists and Cesar Chavez's United Farm Workers." Although the Journal conceded that "Mexican-Americans and other 'language minorities'... have indeed been victims of discrimination," the conservative newspaperlike Murchison-wondered if perhaps the "protection of the act of voting" had become "subordinated to the goal of guaranteeing a minority quota in the results." 139 Though drawing different conclusions, more liberal observers writing in The Nation shared the same view of the significance of the McAllen vote. "The election was marked by charges of racism, police brutality and labor-baiting, and by allegations that 'outside influences' were trying to take over the government, and it left deep scars in the body politic," they wrote. "The election may have set the tone for future area clashes between Anglo and Mexican-American voters, and the tactics employed by the winner underscore the need for the renewal of the Voting Rights Act." 140

Historians have rightly pointed to the landslide victory of Henry Cisneros in the 1981 mayoral election in San Antonio as a moment of tremendous significance because a Mexican American candidate defeated the incumbent Anglo with a coalition of Mexican American, black, and minority Anglo support, and became one of the first Hispanic mayors of a major American city. "The election of Cisneros and the subsequent rise of other Mexican American politicians were visible signs of a fundamental shift in ethnic and class relations in San Antonio," noted David Montejano. “This new political order represented an 'understanding,' or convergence, between Anglo business interests and those of the Mexican American middle and working classes, with the former seeking support for their economic proposals, and the latter seeking support for their political ambitions." 141

Overlooked by historians, the mayoral campaign in McAllen adds complexity to the story of political ascendancy for Mexican Americans in 1981, reinforcing some and challenging other conclusions resulting from the Cisneros victory. As in San Antonio, Mexican Americans displayed extraordinary energy in supporting a Mexican American candidate, in registering to vote, and then in casting votes-in record numbers. As in San Antonio, Mexican Americans were eager to dislodge the Anglos who for many decades had syphoned off political and economic benefits for their own communities and denied them to Mexican 
Americans. Unlike in San Antonio, however, the Anglo candidate and his supporters were successful in their appeals to racism and classism, stymying the efforts of the activists. Unlike in San Antonio as well, the Anglo candidate maintained his lock on the city leadership for another two decades. As a consequence of this comparison of the similarities and dissimilarities in the mayoral elections in McAllen and San Antonio in 1981, scholars can better appreciate the fervor and scope of Mexican American activism in the early 1980s and at the same time remain somewhat cautious about a sometimes-triumphalist narrative about that period. The Nation made a similar point in its 1981 story: "Last spring, when Henry Cisneros surprised Texas and the nation by easily and peacefully winning the mayoral election in San Antonio, thus becoming the only Mexican-American leader of a major U.S. city, things were quite different 250 miles to the south in the city of McAllen."142

\section{Acknowledgments}

I thank Walter Diaz, Evren Turan, Jerry Polinard, José Antonio Rodríguez, Sean Visintainer, and Adela Cadena for their contributions to this work. For a Faculty Research Grant in support of it, I thank the Office of Global Engagement at the University of Texas Rio Grande Valley.

\section{Notes}

1. David McLemore, "Revelations of Beatings Place McAllen Police under Spotlight," Dallas Morning News, March 29, 1981, 38A.

2. Ibid.

3. Ibid.

4. David McLemore, "McAllen Inquiry Widens," Dallas Morning News, May 3, 1981, 47A.

5. Marc Simon Rodriguez, Rethinking the Chicano Movement (New York: Routledge, 2014), 57. See also Brian D. Behnken, Fighting Their Own Battles: Mexican Americans, African Americans, and the Struggle for Civil Rights in Texas (Chapel Hill: University of North Carolina Press, 2011), esp. 154-194; David Montejano, Quixote's Soldiers: A Local History of the Chicano Movement, 1966-1981 (Austin: University of Texas Press, 2010), 131; Ernesto B. Vigil, The Crusade for Justice: Chicano Militancy and the Government's War on Dissent (Madison: University of Wisconsin Press, 1999), passim; Juan Gómez-Quiñones, Chicano Politics: Reality and Promise, 1940-1990 (Albuquerque: University of 
New Mexico Press, 1990), 41; Juan Gómez-Quiñones and Irene Vásquez, Making Aztlán: Ideology and Culture of the Chicana and Chicano Movement, 1966-1977 (Albuquerque: University of New Mexico Press, 2014), 202-204.

6. For a recent study of police violence against Mexican Americans in Texas, see Brent M. S. Campney, “The Most Turbulent and Most Traumatic Years in Recent Mexican-American History': Police Violence and the Civil Rights Struggle in 1970s Texas," Southwestern Historical Quarterly (July 2018): 32-57.

7. Dan Balz, "Brutality Charges, Bitterness Haunt McAllen, Tex.," Washington Post, June 2, 1981, https://www.washingtonpost.com/archive/politics/ 1981/06/02/brutality-charges-bitterness-haunt-mcallen-tex/ddf97d23-83c9-4ca8a6fa-296caadff557/?utm_term=.2eb965318f4e [accessed August 10, 2017].

8. 1980 Census of Population: Volume 1, Characteristics of the Population, Chapter A, Number of Inhabitants, Part 45, Texas (Washington, D.C.: U.S. Department of Commerce, 1982), 55 .

9. Benjamin Heber Johnson, Revolution in Texas: How a Forgotten Rebellion and Its Bloody Suppression Turned Mexicans into Americans (New Haven: Yale University Press, 2003); David Montejano, Anglos and Mexicans in the Making of Texas, 1836-1986 (Austin: University of Texas Press, 1987), 117-119, 121, 125; William D. Carrigan and Clive Webb, Forgotten Dead: Mob Violence against Mexicans in the United States, 1848-1928 (New York: Oxford University Press, 2013), 22-23, 85-86.

10. On the continual resurrection of Jim Crow indignities, see Behnken, Fighting their own Battles, 37. On LULAC, see Craig A. Kaplowitz, LULAC, Mexican Americans, and National Policy (College Station: Texas A\&M Press, 2005); Cynthia E. Orozco, No Mexicans, Women, or Dogs Allowed: The Rise of the Mexican American Civil Rights Movement (Austin: University of Texas Press, 2009).

11. Timothy Paul Bowman, Blood Oranges: Colonialism and Agriculture in the South Texas Borderlands (College Station: Texas A\&M University Press, 2016), 164.

12. Behnken, Fighting Their Own Battles, 106.

13. Quoted in Bill Moyers, Listening to America: A Traveler Rediscovers His Country (New York: A Harper's Magazine Press Book, 1971), 233, 234.

14. "An Open Letter from a Citizen Who Loves and Is Concerned about McAllen," Monitor (McAllen), April 30, 1981, 3A.

15. "Jurors Indict Valley Lawman," Dallas Morning News, March 1, 1971, $12 \mathrm{C}$.

16. "Bryan," Brownsville Herald, December 30, 1970, 8.

17. "Angry, Shouting Chicanos March on Home of Sheriff of San Benito," Pampa Daily News, January 25, 1971, 2.

18. "Jury Finds Innocent for Deputy," Dallas Morning News, April 30, 1971, $12 \mathrm{~A}$. 
19. "Murder in Pharr," Grito del Norte (Las Vegas, New Mexico), February 28, 1971, 3. For more on police violence in Pharr, see David M. Fishlow, "Poncho Flores is Dead," Texas Observer, in "Chicano Collection," Special Collections, Archives, University of Texas Rio Grande Valley (F381- Hidaglo CountyPharr-Pharr Riot, Copy 1).

20. "Massed Police Quell Youth Riot at Pharr," Monitor (McAllen), February 7, 1971, 1 .

21. "Murder in Pharr," Grito del Norte (Las Vegas, New Mexico), February $28,1971,3$.

22. Ibid.

23. "Chavez," Monitor (McAllen), February 9, 1971, 3.

24. David McLemore, "Revelations of Beatings Place McAllen Police under Spotlight," Dallas Morning News, March 29, 1981, 38A.

25. David Hanners, "Former Officers Indicted," Dallas Morning News, November 5, 1981, 46A.

26. "Mexican-American Caucus Sees McAllen Police Tapes," Monitor (McAllen), April 29, 1981, 8A.

27. “Chavez," Monitor (McAllen), February 9, 1971, 3.

28. David McLemore, "Revelations of Beatings Place McAllen Police under Spotlight," Dallas Morning News, March 29, 1981, 38A.

29. “People's Voice," Monitor (McAllen), May 6, 1981, 6A.

30. David Sedeno, "McAllen Mayor Controversial Character," Seguin GazetteEnterprise, August 4, 1985, 7A.

31. “The Last Patrón,” Texas Monthly, July 1981, 86.

32. David Sedeno, "McAllen Mayor Controversial Character," Seguin GazetteEnterprise, August 4, 1985, 7A.

33. “The Last Patrón," Texas Monthly, July 1981, 86.

34. David Sedeno, "McAllen Mayor Controversial Character," Seguin GazetteEnterprise, August 4, 1985, 7A.

35. Ibid.

36. “The Last Patrón," Texas Monthly, July 1981, 86.

37. David Sedeno, "McAllen Mayor Controversial Character," Seguin GazetteEnterprise, August 4, 1985, 7A.

38. Ibid.

39. "Frost Criticizes Brand's Leadership," Monitor (McAllen), March 26, $1981,8 \mathrm{~B}$.

40. "The Law According to Othal Brand," Monitor (McAllen), March 27, 1981, 3A.

41. David Sedeno, "McAllen Mayor Controversial Character," Seguin GazetteEnterprise, August 4, 1985, 7A. 
42. "Farmworkers Won't Give Up Mayor's Office," Dallas Morning News, January 24, 1981, 20A.

43. "The Last Patrón," Texas Monthly, July 1981, 86.

44. Ibid.

45. "Violence Narrowly Averted in Field Hand Organizing Try," Valley Morning Star (Harlingen), May 30, 1975, 1.

46. David Sedeno, "McAllen Mayor Controversial Character," Seguin GazetteEnterprise, August 4, 1985, 7A.

47. “The Last Patrón," Texas Monthly, July 1981, 86.

48. "210 Farmers Arrested for Blocking Rio Grande Bridge," State Times Advocate (Baton Rouge, Louisiana), March 2, 1978, 9A.

49. "McAllen Police Praised, Hill's Actions Criticized," Dallas Morning News, March 8, 1978, 19A.

50. David McLemore, "Revelations of Beatings Place McAllen Police under Spotlight," Dallas Morning News, March 29, 1981, 38A. For a list of some of these cases, see "Suits and Plaintiffs against McAllen Police," Box 1, Folder 7, "Brand's Defamations, 1981, 1983," in Dr. Ramiro R. Casso Papers, 19602007, Benson Latin American Collection, University of Texas Libraries, the University of Texas at Austin (hereafter Casso Papers).

51. David Hanners, "Judge Denies Move to Bar Videotapes," Monitor (McAllen), March 24, 1981, 1A.

52. David Hanners, "Harrington Says City Aware of Misconduct," Monitor (McAllen), March 16, 1981, 1A.

53. David McLemore, "Revelations of Beatings Place McAllen Police under Spotlight," Dallas Morning News, March 29, 1981, 38A.

54. David Hanners, "Officers Said Trained to 'Get Even' with Prisoners," Monitor (McAllen), March 25, 1981, 1A.

55. "Police," Monitor (McAllen), March 27, 1981, 10A.

56. David Hanners, "Officers Said Trained to 'Get Even' with Prisoners," Monitor (McAllen), March 25, 1981, 1A.

57. David Hanners, “Tapes Raise Question about Confiscated Pot," Monitor (McAllen), May 22, 1981, 3D.

58. "Memorandum," August 2, 1978, [p. 1], Box 1, Folder 7, Casso Papers.

59. "Memorandum," August 2, 1978, [p. 2], Box 1, Folder 7, Casso Papers.

60. George Kuempel, "McAllen Mayor Knew of Abuse, Lawyer Says," Dallas Morning News, April 10, 1981, 17A.

61. Memo by Gary Miller, Sergeant, Patrol Division, [undated], in Box 1, Folder 7, Casso Papers.

62. George Kuempel, "McAllen Mayor Knew of Abuse, Lawyer Says," Dallas Morning News, April 10, 1981, 17A. 

2C.

63. "Image of Police Badly Tarnished," Monitor(McAllen), March 29, 1981,

64. "People's Voice," Monitor (McAllen), April 14, 1981, 8A.

65. Dan Balz, "Brutality Charges, Bitterness Haunt McAllen, Tex.," Washington Post, June 2, 1981, https://www.washingtonpost.com/archive/ politics /1981/06/02/brutality-charges-bitterness-haunt-mcallen-tex / ddf97d23-83c9-4ca8-a6fa-296caadff557/?utm_term=.2eb965318f4e [accessed August 10, 2017]

66. David McLemore, "Revelations of Beatings Place McAllen Police under Spotlight," Dallas Morning News, March 29, 1981, 38A.

67. “People's Voice," Monitor (McAllen), May 7, 1981, 2 E.

68. "People's Voice," Monitor (McAllen), May 5, 1981, 6A.

69. “People's Voice," Monitor (McAllen), May 6, 1981, 6A.

70. "Harrington Warns Police Brutality Will Continue," Monitor (McAllen), April 27, 1981, 3A.

71. "People's Voice," Monitor (McAllen), April 10, 1981, 2 D.

72. "Bonilla Lashes Out at Brand in Speech," Monitor (McAllen), May 17, $1981,12 \mathrm{~A}$.

73. Marcia Caltabiano, "Situation Tense at Police Department," Monitor (McAllen), April 27, 1981, 1A. On the various investigations and restructuring efforts, see Gail Sammons and Virginia Armstrong, "Police Board Is Changed after Contempt Motion," Monitor (McAllen), April 8, 1981, 1A; Virginia Armstrong, "Makeup of Police Board Is Revised," Monitor (McAllen), April 10, 1981, 1A; Virginia Armstrong, "Chief Picks Woman Officer," Monitor (McAllen), April 14, 1981, 1A; "White Promising Probe of Police," Monitor (McAllen), April 30, 1981, 1A; Virginia Armstrong, "New Police Training Program to Be Implemented in June," Monitor (McAllen), May 24, 1981, 3A.

74. David Hanners, "Former Officers Indicted," Dallas Morning News, November 5, 1981, 46A.

75. David Hanners, "Brutality Case Ends in Mistrial," Dallas Morning News, January 19, 1982, 8B.

76. "Hospital Sale Stirs Debate," Dallas Morning News, January 7, 1980, $10 \mathrm{~A}$.

77. Sydney Rubin, "Hispanics Seek Mayoral Win in McAllen," Dallas Morning News, February 12, 1984, 52A.

78. Virginia Armstrong, "Election," Monitor (McAllen), May 11, 1981, $12 \mathrm{~A}$.

79. Sydney Rubin, "Hispanics Seek Mayoral Win in McAllen," Dallas Morning News, February 12, 1984, 52A.

80. Juan Castillo, "Farm Workers Voice Plans to Be More Politically Active," Monitor (McAllen), May 8, 1981, 3A. 
81. "Farmworkers Won't Give Up Mayor's Office," Dallas Morning News, January 24, 1981, 20A.

82. Sydney Rubin, "Hispanics Seek Mayoral Win in McAllen," Dallas Morning News, February 12, 1984, 52A.

83. "Letter to the Editor," Monitor (McAllen), March 29, 1981, 3C.

84. "An Open Letter from a Citizen Who Loves and Is Concerned about McAllen," Monitor (McAllen), April 30, 1981, 3A.

85. "McAllen Re-Elects Mayor," Dallas Morning News, May 10, 1981, 42A.

86. "Hispanic Runs Strong Race against Brand," Dallas Morning News, May $9,1981,37 \mathrm{~A}$.

87. “Image of Police Badly Tarnished," Monitor (McAllen), March 29, 1981, 2C.

88. David Hanners, "Officers Said Trained to 'Get Even' with Prisoners," Monitor (McAllen), March 25, 1981, 1A. Brand denied that he ordered the erasing of the videotapes and claimed that "the only order to erase any tapes involved phone calls in the police station. The city commission had passed an ordinance earlier ordering that taping of all calls in and out of the station be stopped, other than calls to the dispatcher." Brand claimed that his concern was with preventing warring factions within the MPD of recording one another's calls. See "Brand Denies He Ordered Police Videotapes Erased," Monitor (McAllen), March 25, 1981, 1A.

89. David Hanners, "Probe by Outside Agency Is Favored," Monitor (McAllen), March 26, 1981, 1A.

90. Gail Sammons, "Governor Asked to Withdraw Selection of Brand to Board," Monitor (McAllen), April 3, 1981, 1A.

91. Laurence H. Gross, "Nomination of Brand Defended," Monitor (McAllen), April 7, 1981, 1A.

92. On the Brand nomination, the police violence, the mayor's withdrawal and then his decision to face the confirmation hearings, and the opposition to his nomination by State Senator Hector Uribe, see "Brand Nominated for Prison Board," Monitor (McAllen), April 13, 1981, 1A; "Brand Withdraws Board Nomination," Monitor (McAllen), April 27, 1981, 1A; "Tape Question Triggers Confusion," Monitor (McAllen), May 20, 1981, 1A; "Senate Panel to Make No Recommendation," Monitor (McAllen), May 21, 1981, 1A; "Uribe Says No to Brand Nomination," Monitor (McAllen), May 22, 1981, 1A; "Brand Raps Urbie [sic] Action," Monitor (McAllen), May 22, 1981, 1A.

93. "Hearing on Brand Was Cut and Dried," Monitor (McAllen), May 24, $1981,5 \mathrm{~A}$.

94. Virginia Armstrong, "Casso, Brand Face Runoff for Mayor," Monitor (McAllen), April 5, 1981, 1A.

95. John Lovelady, "Election Inspector Report," April 4, 1981, 1, Box 1, Folder 7, Casso Papers. 
96. Cary Hatch, "Election Inspector Report,” April 4, 1981, 1, Box 1, Folder 7, Casso Papers.

97. Ibid. On Frost and his supporters, see Virginia Armstrong, "Big Turnout Seen for Mayor's Race," Monitor (McAllen), April 3, 1981, 1A. Frost enjoyed the support of "the business community who dominated local politics for many years" until Brand emerged as a formidable leader in the mid-1970s.

98. Virginia Armstrong, "Mayor," Monitor (McAllen), April 5, 1981, 10A.

99. "2,000 Turn Out to Kick Off Brand Campaign," Monitor (McAllen), April 15, 1981, 12A. $42 \mathrm{~A}$.

100. "McAllen Re-Elects Mayor," Dallas Morning News, May 10, 1981,

101. "Hispanic Runs Strong Race against Brand," Dallas Morning News, May 9, 1981, 37A.

102. "McAllen Re-Elects Mayor," Dallas Morning News, May 10, 1981, $42 \mathrm{~A}$.

103. Virginia Armstrong, "Candidates," Monitor (McAllen), March 27, 1981, 10A.

104. David Hanners, "Judge Denies Move to Bar Videotapes," Monitor (McAllen), March 24, 1981, 1A.

105. Marcia Caltabiano, "Protest March," Monitor (McAllen), February 22, 1982, 12A.

106. “People's Voice," Monitor (McAllen), May 7, 1981, 2E.

107. "People's Voice," Monitor (McAllen), May 3, 1981, 12E.

108. Dan Balz, "Brutality Charges, Bitterness Haunt McAllen, Tex.," Washington Post, June 2, 1981, https://www.washingtonpost.com/archive/ politics / 1981/06/02/brutality-charges-bitterness-haunt-mcallen-tex / ddf97d23-83c9-4ca8-a6fa-296caadff557/?utm_term=.2eb965318f4e [accessed August 10, 2017].

109. "McAllen Re-Elects Mayor," Dallas Morning News, May 10, 1981, $42 \mathrm{~A}$.

110. Juan Castillo, "Farm Workers Voice Plans to Be More Politically Active," Monitor (McAllen), May 8, 1981, 3A.

111. "Now...Do You Have Any Doubts?” Monitor (McAllen), May 8, 1981, 3A. On Brand's charges that "much of Casso's support comes from 'outsiders," and particularly from the union, see Virginia Armstrong, "Vote," Monitor (McAllen), May 8, 1981, 12A, and "Who Is Really Mayor Brand's Opponent?" Monitor (McAllen), May 8, 1981, 3A.

112. "These Are the Questions People Are Asking of Dr. Casso," Monitor (McAllen), May 5, 1981, 3A.

113. "Hispanic Runs Strong Race against Brand," Dallas Morning News, May $9,1981,37$ A. 
114. "People's Voice," Monitor (McAllen), May 7, 1981, 2E.

115. "People's Voice," Monitor (McAllen), March 1, 1981, 12C.

116. "Let's Get the Facts Straight," Monitor (McAllen), May 8, 1981, 9A.

117. "Voter Fraud Alleged in McAllen," Dallas Morning News, April 1, 1981, $23 \mathrm{~A}$.

118. "Mayor Claims Irregularities Uncovered in Lists of Voters," Monitor (McAllen), March 30, 1981, 1A.

119. Virginia Armstrong, "Vote," Monitor (McAllen), May 8, 1981, 12A.

120. "Southwest Voter Registration Education Project," May 4, 1981, 1, 3, Box 1, Folder 7, Casso Papers.

121. Gail Sammons, "Racism, Dirty Politicking Charges Exchanged by Mayor Candidates," Monitor (McAllen), May 7, 1981, 1A.

122. Virginia Armstrong, "Vote," Monitor (McAllen), May 8, 1981, 12A.

123. Virginia Armstrong, "City of Palms," Monitor (McAllen), May 3, 1981, 6 A.

124. Virginia Armstrong, "City to Pick Mayor Saturday," Monitor (McAllen), May 8, 1981, 1A.

125. Virginia Armstrong, "Election," Monitor (McAllen), May 10, 1981, $8 \mathrm{~A}$.

126. Virginia Armstrong, "Casso, Brand Face Runoff for Mayor," Monitor (McAllen), April 5, 1981, 1A, 10A.

127. Dan Balz, "Brutality Charges, Bitterness Haunt McAllen, Tex.," Washington Post, June 2, 1981, https://www.washingtonpost.com/archive/ politics/1981/06/02/brutality-charges-bitterness-haunt-mcallen-tex/ddf97d2383c9-4ca8-a6fa-296caadff557/?utm_term=.2eb965318f4e [accessed August $10,2017]$.

128. Virginia Armstrong, "Brand Captures New Term," Monitor (McAllen), May 10, 1981, 1A. The Wall Street Journal had a somewhat different take: “Casso's high Mexican-American turnout was beaten by an even higher Anglo turnout." However, it added, "Casso really lost the election in absentee voting, which remains unfamiliar to Mexican Americans. Many of them in any event are on the road as migrant workers, opening a question about the scheduling of the election." See "Voting Rights in the Valley," Wall Street Journal, May 12, 1981, 22, Box 1, Folder 7, Casso Papers.

129. Virginia Armstrong, "Analysis Indicates Vote Not on Ethnic Lines," Monitor (McAllen), May 24, 1981, 5A. Although the figures in Armstrong's May 10 and May 24 stories are not the same, the latter reflect adjusted numbers.

130. Susan Stoler, “Texas Voters Pick Incumbent," Oregonian (Portland, Oregon), May 11, 1981, Al0.

131. Sydney Rubin, "Hispanics Seek Mayoral Win in McAllen," Dallas Morning News, February 12, 1984, 52A. 
132. William Murchison, "It's Time to Move On," Dallas Morning News, May 28, 1981, A24.

\section{Ibid.}

134 Dan Balz, "Brutality Charges, Bitterness Haunt McAllen, Tex.," Washington Post, June 2, 1981, https://www.washingtonpost.com/archive/ politics/1981/06/02/brutality-charges-bitterness-haunt-mcallen-tex/ddf $97 \mathrm{~d} 23$ -83c9-4ca8-a6fa-296caadff557/?utm_term=.2eb965318f4e [accessed August $10,2017]$.

135. "People's Voice," Monitor (McAllen), May 26, 1981, 6A. A friend of the fallen officer bitterly linked the death of Suarez and "a recent rash of police brutality lawsuits against McAllen police." In law enforcement, he said, "we can't afford to hesitate one bit" because "[a]nytime you hesitate, even for one second, you're in trouble." He concluded that it was possible that hesitation on Suarez's part "may have led to his death....'With all these lawsuits, I think every officer has this thing in the back of his mind.... They get to the point where they hesitate and ask, "Am I going to get sued or indicted or something?" , " See "Police Officer Killed," May 19, 1981, UPI Archives, https://www.upi.com/ Archives /1981/05/19/Police-officer-killed/7911359092800/[accessed August 8, 2018].

136. “450 Protesters March for 'Justice' in McAllen,” Dallas Morning News, February 22, 1982, 21A. A critic mourned that " "most of the jury were business people and few were Mexican-Americans,' she said. 'The jury did not represent our community.' "See "March Called in Protest of Police Verdict," Monitor (McAllen), February 17, 1982, 1D.

137. Marcia Caltabiano, "Crowd of 450 Marches in Protest of Police Verdict," Monitor (McAllen), February 22, 1982, 1.

138. See, for example, Ernesto Chávez, ¡Mi Raza Primero! (My People First!): Nationalism, Identity, and Insurgency in the Chicano Movement in Los Angeles, 1966-1978 (Berkeley: University of California Press, 2002), 118-119; Montejano, Anglos and Mexicans, 289.

139. "Voting Rights in the Valley," Wall Street Journal, May 12, 1981, 22, Box 1, Folder 7, Casso Papers.

140. David C. Kibbe and Kenneth Bain, "Patrón Politics in McAllen, Texas," The Nation, September 26, 1981, 268, Box 1, Folder 14, "Newspaper Clippings, 1981-1985," Casso Papers.

141. Montejano, Quixote's Soldiers, 253-254.

142. David C. Kibbe and Kenneth Bain, "Patrón Politics in McAllen, Texas," The Nation, September 26, 1981, 268, Box 1, Folder 14, "Newspaper Clippings, 1981-1985," Casso Papers. 